NGTT Deel 54, Nommers 3 \& 4, September en Desember 2013

Fouché, Leon

Stellenbosch University

\title{
Orientation and ambiguity - On a decisive hermeneutical dimension in Dirkie Smit's theological thinking
}

\begin{abstract}
This essay explores Dirkie Smit's theological thinking from a hermeneutical perspective. Smit's linking up with Karl Barth's view on confessing, as can be seen in the Accompanying Letter of the Belhar Confession, is taken as illustration. After a historical perspective on the philosophical hermeneutics of Hans-Georg Gadamer with its central concepts of historicality, contextuality, orientation and dialogue, it is demonstrated how these concepts also play a significant role in Smit's way of doing theology. Barth's three aspects of Reformed confessions (historical context, the one message and the one church) are associated with three Gadamer's concepts of historicality, orientation and contextuality. While Gadamer's philosophical hermeneutics move from application (contextuality) to practical philosophy, Smit's theology moves from contextuality to public theology. Confessing the old Christian creed that Jesus is Lord in the public sphere as the church's decisive orientation contains the risk of ambiguity within an ongoing dialogue. The argument of the article is that the core of Smit's theological thinking can be understood as orientation and ambiguity amidst the dialectic of historicality and contextuality.
\end{abstract}

\section{INTRODUCTION}

In this essay the core of Dirkie Smit's theological thinking will be explored from a hermeneutical perspective. The focus is not on his theory of hermeneutics, but on his theology; not on his thinking about how understanding happens, but on a decisive hermeneutical dimension in his thinking about God. Although Smit is well aware of the ongoing debates in hermeneutical thinking and had written a book and several articles on it (Smit 1987, 1998a and 1998b), the primary focus of his thought is not hermeneutics, but theology. It is like Gerhard Ebeling's statement about Luther's hermeneutics: He didn't introduce a new kind of hermeneutics, but discovered the gospel in a new way and, by discovering the gospel in a new way, a new hermeneutics was constituted (Ebeling 1969:275-276). Smit's way of doing theology explores the gospel in a refreshing way. By doing this he opens up several exciting hermeneutical dimensions. In this article the question simply concerns a decisive hermeneutical aspect of his theology.

To answer this question, I will first give a historical perspective on the most important aspect of the philosophical hermeneutics of HansGeorg Gadamer, namely the problem of "application". This aspect resonates with a decisive hermeneutical dimension in Smit's theological thinking. I will illustrate this by his reference to Karl Barth's view on confessing, as can be seen in the Accompanying Letter to the Belhar Confession. With this approach I would like to argue that, from a hermeneutical perspective, the core of Smit's theological thinking can be understood as orientation and ambiguity amidst the dialectic of historicality and contextuality. 
NGTT: Oopbron - http://ngtt.journals.ac.za

\section{GADAMER: FROM APPLICATION TO PRACTICAL THEOLOGY}

\section{The problem of application}

Schleiermacher, the father of modern hermeneutics who introduced a general hermeneutics of understanding, excludes application from his hermeneutics. According to him, application is not part of the act of understanding. Application is a separate action following the completed act of understanding. Schleiermacher refers to Ernesti's distinction between three "abilities" or "arts" - subtillitas intelligendi, subtillitas explicandi and subtillitas applicandi. According to Schleiermacher, hermeneutics has to do only with the subtillitas intelligendi - it is the art or ability to understand. The art to explain is part of hermeneutics only in so far as it is the explication of what is already understood. The moment explication becomes a creative activity it is already part of rhetoric (Schleiermacher 1974:31; Fouché 1978:49-50).

The way Schleiermacher's hermeneutics developed cancelled his initial approach so that understanding and explication became intertwined and inse parable. ${ }^{1}$ However, his exclusion of application from the heart of hermeneutical thinking is precisely the Achilles heel of his thinking. This redirected his her meneutics to focus on the true intention of the author instead of on the truth intended by the author (Fouché 1978:104-105).

For Gadamer application is not a separate action that follows on an indepen dent and completed act of understanding. In his answer to the main question posed in his magnum opus Wahrheit und Methode (Truth and Method) - "What happens when we understand?" (Gadamer 1975:XVI) - application or the truth or relevance of what we understand is indissolubly part of the process of understanding. The reason for this is his concept of historicality by which understanding is not primarily an act of the human subject, but a happening within the overwhelming, powerful working of history by which we are transformed. This concept of historicality opens up a whole new view and experience of the process of understanding of which application forms part (Gadamer 1975:157-161, 290-323; Fouché 2001:71-88).

\section{From historicality to dialogue}

Gadamer's concept of history ${ }^{2}$ is not the romantic idea of a wonderful past that can be studied by gathering bits and pieces as positive facts. It is not even the idea of an ongoing and never-ending movement of occurrences which can be viewed from some point of reference. History is rather the allencapsulating and overwhelming power of occurrences that not only transforms us, but is always already accompanying us on our way. There is no point of view outside time and space from where one can observe and interpret history, one is always already part of ongoing occurrences, always already making sense of them, and frequently reinterpreting them according to new situations (Gadamer 1975:250-290). In short, one is not (like riverrafting adventurers) standing on a hilltop searching for appropriate routes around the rocks within the rapids, one finds oneself within the rapids and challenged to navigate

1 The reason for this is simply Schleiermacher's strong convictions on the identity of language and thought throughout his hermeneutical journey in his earlier and later phases - this view differs from Kimmerle (Kimmerle 1957; Fouché 1978:46-48, 83-93).

2 Gadamer's concept of history can at best be translated as "historicality". Historicity denotes the mere ongoing flow of history; historicality is the noun referring to something which is "historical" in the sense that it is happening and is meaningful ... that we are also involved in this meaningful "happening" is not directly seen in the word, but should be explained. 
NGTT Deel 54, Nommers $3 \& 4$, September en Desember 2013

without any view from above. One can do no other than to change strategy with every new view of the oncoming, dangerous rocks.

Gadamer uses different metaphors to illustrate how understanding takes place within the movement of historicality (for example, "fusion of horizons", "dialogue", "tragedy", et cetera) and the metaphor of dialogue serves as a model. We are encapsulated in tradition, an interpreted tradition or living awareness of the truth claim of tradition. One lives within an always already meaningful tradition that does not lie behind one, belonging to the past, but that remains relevant. One remains in a constant dialogue with tradition. When one's understanding works properly, this dialogue is, according to Gadamer, not the type of dialogue where tradition as the counterpart of dialogue amounts to mere facts (as in the positive sciences) or a romantic and very interesting past (as in the methods of historism), but rather as a "you" where the otherness of the other is acknowledged and where one is open to correction and enrichment. ${ }^{3}$ Tradition is like a "you" that is not "I" and that can tell me something I do not know. In a dialogue with such a counterpart, the outcome is not the standpoint of the one or the other, but rather something which is new. That which is new is something which one could never have come to was it not for the dialogue (Gadamer 1975:329-360; Fouché 2001:88-95; Fouché and Smit 1996:80-83). Understanding as a process of historicality is the ongoing dialogue, "the dialogue which we are".

Understanding as a constant dialogue with a relevant tradition where new meaning is generated, is always already "applied". Understanding is constantly evolving from application as the ongoing realisation of the relevance or truth claim of what one is trying to understand. The notion of application in Gadamer's hermeneutics differs from Schleiermacher's banning of it to some other discipline outside of the field of hermeneutics; application is drawn into - or rather, is recognised as being at - the centre of hermeneutics.

\section{From dialogue to practical philosophy}

The "I" of the dialogue is not a bloodless or abstract subject who registers positive and objective facts, but an involved "I" - passionately involved as a human being fluctuating between hope and despair. In Gadamer's hermeneutics understanding is not a purely intellectual activity; it is a process of involvement and action. It can be illustrated in his use of Aristotle's definition of tragedy, as well as in his linking up with the key concept of phronesis in Aristotle's ethics.

Aristotle gives a remarkable definition of tragedy. His definition includes not only that which occurs onstage, but also what happens to the audience offstage. A tragedy creates emotions of eleos and phobos (sorrow and fear) in the audience - sorrow for the person who experiences such a tragic event and fear for the possibility that it might happen to themselves (Gadamer 1975:122-127; Fouché 2001:64-67). The "I" in the process of understanding is not bloodless but humane.

What is more, understanding that incorporates application is not only emotional involvement,

3 For Gadamer, the hermeneutic experience is a Hegelian dialectic: The world is different from what one thinks it is, it is learning through faults and correction like Aeschylus's pathei mathos - learning through suffering.

4 This is the phrase with which Gadamer links up with a poem of Hölderlin (Friedensfeier): "Seit ein Gespräch wir sind und hören können von einander" (Since we are a dialogue and we are able to listen to each other). 
NGTT: Oopbron - http://ngtt.journals.ac.za

it is also an involvement of the will resulting in deliberate decisionmaking and action. To illustrate this Gadamer refers to Aristotle's concept of phronesis. According to Aristotle, we do not really know what the good, which should be practised in every situation, is. We do not even have a clear concept of what the good is - we have only a vague and general idea of this good. In the light of our vague and general idea of what is good, we have to weigh up the different possibilities against each other in every concrete and particular situation in order to act. This is the activity of phronesis, common sense or prudent judgement. The weighing up of possibilities is not solely a matter of intellectual playfulness; it ends in a decision to act. Gadamer uses Aristotle's idea of phronesis as metaphor for how understanding happens. Understanding is also the prudent activity of connecting the general with the particular, the common-sense deliberation on how the general truth claim of tradition connects to the particular situation and what it compels us to think and to do (Gadamer 1975:295-307).

Understanding happens in the same way as phronesis in practical philosophy. Practical philosophy is not - as we tend to think - the application of some theoretical idea; it is rather a philosophy of praxis ${ }^{5}$ (Gadamer 1974, 1976a, 1976b, 1980, 1983, 1999; Fouché 2001:128-141; Bernstein 1982; Foster 1991; Riedel 1972 and 1974). Praxis is also the everyday life of decisionmaking regarding what is good and useful for the community and what is bad and should be rejected for the sake of a humane society. Logical reasoning results in a statement or theory; within practical philosophy practical reasoning results in a decision to act. Understanding functions within practical philosophy as phronesis (practical reasoning or common-sense deliberation). Its conclusion is not a theoretical statement, but a practical decision on a new orientation towards life and action.

It is for this reason that Gadamer typifies hermeneutics as practical philosophy and views understanding as phronesis. For him, hermeneutics is the heir of practical philosophy - the vindicating of the noble task of the citizen, namely decisionmaking according to one's own deliberation and responsibility instead of leaving it to the experts (Gadamer 1976a, 1976b; Dutt 1995:71-72).

\section{DiRKIE SMIT: FROM CONTEXTUALITY TO PUBLIC THEOLOGY}

From the above historical perspective on Gadamer's philosophical hermeneutics a decisive hermeneutical dimension in Smit's theology is quite obvious. The prominent characteristic of Gadamer's hermeneutics is his incorporation of the problem of application within the centre of understanding that transforms the face of hermeneutics to practical philosophy; a decisive hermeneutical dimension in Smit's way of doing theology is contextuality, which transforms the face of theology to public theology (Cf. Smit 2007a \& 2008).

To illustrate this I refer to the motivation for the Belhar Confession found in the Accompanying

\footnotetext{
5 Aristotle differentiates between three types of knowledge - episteme, phronesis and techne. Episteme refers to exact knowledge, such as mathematics, and techne to knowledge as the skill to produce something exactly according to a blueprint. Phronesis is practical reasoning within the field of uncertainty - the everyday life in the community or praxis. Practical philosophy is philosophy of praxis. In episteme and techne the teacher has the exact knowledge and teaches the student who knows nothing; in phronesis within practical philosophy the more experienced one teaches the less experienced one and both ask, from a position of uncertainty and of not knowing, what the best conduct would be. The choice for the best conduct is made from phronesis or common sense.
} 
NGTT Deel 54, Nommers $3 \& 4$, September en Desember 2013

Letter (which is part of the Confession) - Smit was, of course, instrumental in the formulation of both these documents. The motivation links up with Karl Barth's reasons for the necessity for a church to confess her faith in an official confession, not directly, but broadly speaking. In his essay, No Other Motives Would Give Us the right - Reflections on Contextuality from a Reformed Experience, Smit quotes Barth's definition of a Reformed creed (given in the latter's 1925 lecture "The Desirability and Possibility of a Universal Reformed Creed", at the World Alliance of Reformed Churches in Cardiff): A Reformed creed is the statement, spontaneously and publicly formulated by a Christian community within a geographically limited area, which, until further action, defines its character to outsiders; and which, until further action, gives guidance for its own doctrine of life; it is a formulation of the insight currently given to the whole Christian Church by the revelation of God in Jesus Christ, witnessed to by Holy Scriptures alone (Smit 2007b:159).

Smit refers to three key aspects of this definition of a Reformed creed that, although formulated differently, are also found in the Accompanying Letter. These key aspects are the motivation for the creation of the Belhar Confession. They also form the core of Smit's way of doing theology, albeit in a slightly different philosophical perspective.

\section{Three aspects of a Reformed confession}

First: the importance of the historical context. The Accompanying Letter reads: "We are deeply conscious that moments of such seriousness can arise in the life of the Church that it may feel the need to confess its faith anew in the light of a specific situation" (in Smit 2007b:157). This aspect has to do with the historical context, the time, the circumstances, where the truth of the gospel is threatened in such a way that a status confessionis is declared. This compels the church to confess her faith publicly. In this confession the truth of the gospel is to be stated and the misleading lie is to be rejected (Smit 2007b:159-161). Second: the one message. In the words of the Accompanying Letter, "... only if it is considered that the heart of the gospel is so threatened as to be at stake ... Accordingly, we make this confession ... as something we are obliged to do for the sake of the gospel ...." (in Smit 2007b:158).

The Confession is not intended to be a contribution to a debate; it is a cry from the heart. It is done in freedom, without fear and without demands made on anyone; it is done in the hope that others will confess in the same way (Smit 2007b:162-163). Third: the one church. According to the Accompanying Letter,

[t]his confession is not aimed at specific people or groups of people or a church or churches. We proclaim it against a false doctrine, against an ideological distortion which threatens the gospel itself in our church and our country ... We are deeply aware of the deceiving nature of such a false doctrine... Therefore it is that we speak pleadingly rather than accusingly. We plead for reconciliation ... which follows on conversion and change of attitudes and structures ... Our prayer is that this act of confession will not place false stumbling blocks in the way and thereby cause and foster false division, but rather that it will be reconciling and uniting ... We pray that our brothers and sisters throughout the Dutch Reformed Church family, but also outside it, will want to make this new beginning with us, so that we can be free together, and together may walk the road of reconciliation and justice (in Smit 2007b:158-159). 
NGTT: Oopbron - http://ngtt.journals.ac.za

\section{Three philosophical aspects in an on-going dialogue}

From a philosophical and hermeneutical perspective these three key aspects of confession can be associated with three similar philosophical concepts, namely historicality, contextuality and orientation.

The first aspect - the importance of the historical context or the moment of truth - can be associated with the philosophical concept of historicality. His toricality is the powerful working of meaning through history. It comes to the fore in tradition, in creeds and in customs; it is actualised in the understanding of the creeds and the experience of the customs. For this reason it also finds its way into deceiving ideologies and ways of living that make people blind to each other and distorts the truth.

The second aspect - the one message - can be associated with the philosophical concept of orientation. In Aristotle's ethics, orientation is a vague idea of the good. What "the good" really is, is time and again realised and discovered in concrete situations where different possibilities are weighed up against each other and decisions are made. In Smit's theology this orientation can be expressed in the words of the first Christian creed (which is also part of the closing phrases of the Belhar Confession): "Jesus is the Lord". The immediate reaction to this statement may be that this creed is not at all vague or ambiguous. My point is that it has, of course, been clearly stated and confessed for ages, but it is still a vague and ambiguous concept because it is not very clear in every situation what Jesus' Lordship entails. It is rather that we have to pray: Veni Creator Spiritus! We have to seek and discover what the meaning of this crucial and ancient Christian creed is. ${ }^{6}$ This is precisely the endeavour of Smit's theological thinking.

The third aspect - the one church - can be associated with the philosophical concept of contextuality. Contextuality can easily be misunderstood as if it is the interpreting theologian who applies some eternal truth to the context. That will be in line with Schleiermacher's idea of how something that is clearly understood can be applied afterwards. From a Gadamerian perspective as well as from Smit's approach that would be an objectionable idea. Contextuality is, rather, the meaningful possibilities of tradition in our situation in light of the orientation which is the confession that Jesus is Lord.

There exists an ongoing dialogue between historicality, contextuality and orientation. It is possible to differentiate between the different "partners" in the dialogue, but not in any clearcut way as in Gadamer's description of it. In Gadamer's view, dialogue occurs between the interpreter and the historical text. The dialogue has a Hegelian structure of thesis, antithesis and synthesis - the thesis is the preconception (Vorurteil) or preliminary understanding of the text, the antithesis is the text with its traditional meaning, and the synthesis the "fusion of horizons" (the new understanding). There is thus an ongoing movement of to and fro from which a point of view emerges that is not the opinion of the one or the other, but a new point of view.

The dialogue between historicality, contextuality and orientation is even more complex. The interpreter or theologian is not above or against any one of the "partners" in the dialogue, but

6 Peter concluded his sermon on the Day of Pentecost with the Christian creed: "All the people of Israel, then, are to know for sure that this Jesus, whom you crucified, is the one that God has made Lord and Messiah!" (Acts 2:36). However, he still had to learn in humbling ways what this confession entailed once in a vision from God (Acts 10), another time in a public rebuke from Paul! (Gal. 2:11-14). 
NGTT Deel 54, Nommers $3 \& 4$, September en Desember 2013

rather is part of each of them. Historicality, as the tradition of the creeds and customs that is actualised in thinking and experiencing, is an overwhelming power. It can sweep one away toward ideologies that distort the truth and that blind one to proper conduct. Orientation, as the creed "Jesus is Lord", is the default creed of every theologian so that everyone is always already convinced that he or she is thinking and living by this confession. However, this confession often amounts to confusion because of matterofcourse attitudes and unwillingness to be open and to stand corrected. Contextuality, as the meaningful possibility within our context, is also an always already happening in such a way that, within a distorted ideological historical situation, theologians can (and have!) declared that to live as a divided church and to justify a system of injustice is obedience to Jesus as Lord!

The important point to realise is that we are always already drawn into the dialogue of historicality, contextuality and orientation. The crucial question is: How ecumenical is our dialogue? For Smit it is of critical importance that the dialogue with mothers and fathers of the past should go as far back as possible, and the dialogue with sisters and brothers in the present should be as broad as possible. In his paper on the relationship between the socalled contextual and universal theology, he is quite clear:

In continuously searching to remain faithful to this gospel, we are less concerned for "universality", which reflects typically modernist assumptions, but deeply concerned for catholicity and ecumenicity, referring to the fullness of the truth and of the one church of this Triune God, through all ages and in all possible localities, in all its irreducible richness, creaturely, culturally and historically (Smit 2007b:178).

\section{The risk and ambiguity of confession}

Confessing in a historical moment of confusion is running a risk. The confession may be misunderstood, it may be rejected, it may divide instead of unite, it may be ridiculed as a caricature of the truth ... actually, it is not that it "may be...", it is rather that it "will be ...!" In his later work, Karl Barth refers to four characteristics of (the moment of) a confession. They are: (a) confession is "without an ulterior goal" - the only concern is the honour of God; (b) confession rejects unbelief, superstition or heresy and states what is to believed - the "yes" should be heard in the "no"; (c) confession is public - it is not a private affair; (d) confession is an action taken freely - nothing is demanded from anyone (Smit 2007b:161-162).

Every one of these characteristics involves an element of risk. On the first characteristic Smit (following Barth) elaborates:

We aim at no results and expect none. We confess because we cannot keep silent. It is a serious act, but in its freedom from purpose it has more the nature of a game or song than of work or warfare. For this reason confession will always cause headshaking among serious people who do not know the particular seriousness of confession (Smit 2007b:161).

In the words of the Accompanying Letter:

Being fully aware of the risks involved in taking this step, we are nevertheless convinced that we have no alternative. Furthermore, we are aware that no other motives or convictions, however valid they may be, would give us the right to confess in this way ... We do not make this confession from his throne and from on high, but before his throne 
NGTT: Oopbron - http://ngtt.journals.ac.za

and before other human beings (Smit 2007b:158).

An important reason for confessing being such a risky undertaking is because of the ambiguity of what we confess. The old Christian confession that Jesus is Lord will be confirmed by all Christians, but we will differ on its contextual implications, what it means. The Belhar Confession may also be accepted by the Dutch Reformed Church - hopefully in the near future - but we will still need dialogue and debate on what the unity of the church, reconciliation and justice in our country and in every local community actually imply.

The ambiguity of confession is not because it is unclear or untrue; it is rather part of the wonderful richness of what we confess about God. In Christian theology we are not reflecting on an abstract idea that one may call "God"; we are reflecting on the Magnalia Dei, God's saving acts in history - especially on the saving acts of Christ's crucifixion and resurrection, Christ's reign from the right hand of the Father and his second coming. When we reflect on these saving acts, we are doing it from our context. It is not possible to talk about God in an abstract way as if God has nothing to do with the situation in which we find ourselves. It is also not possible to reflect on God's saving acts as if they only affect our innermost lives or some future destiny. Rather, we are compelled to follow God in our context or situation with its grandeur and misère, to confess and live in public.

The ambiguity of confession is also part of being Reformed (Cf. Smit 2009a). Smit refers to Barth's famous answer to the question regarding the possibility of one common confession: it is neither necessary nor possible. Reformed confessions are addressed at the whole church as a call and an appeal; both are authoritative and provisional - "currently", "until further notice". According to Smit, Reformed confessions

are not primarily intended as instruments of unity. In fact, they should probably not be instrumentalised in any way or for any single purpose. Properly understood, they function in a variety of important ways within communities of Reformed faith. They can perhaps originate for one main purpose, and gradually change their function and serve other purposes as well (Smit 2009b:303-304).

By functioning in this way, Reformed confessions indeed serve forms of unity in a variety of ways and as such constitute a "gathering of fragments". As doxologies they provide a common language of faith; as hermeneutical lenses they provide frameworks with which to deal with the diverse and ambiguous collection that is the Bible; as textbooks for instruction they provide orientation and identity (Smit 2009b:304-305). However, the Reformed tradition has

... no central authority, no hierarchical structure, no teaching magisterium, no corpus of infallible doctrine, no common canon of biblical interpretation, no continuous and unchanging liturgical tradition, no charismatic leadership, no basic ethnic or national loyalty, no shared set of religious symbols or legacy of cultic practices, no characteristic kind of religious experience, no special kind of spirituality, not even one common and universal book of confessions. Instead, it is a tradition that claims in radical fashion that it strives to live by "the Bible alone" - and then admits that it has no final interpretation of that Bible and no final authority that can guarantee any interpretation, only a plural and ambiguous confessional tradition (Smit 2009b:305-306).

In a remarkable way this manner of confessing helps Christians to live a life of service and love. 
NGTT Deel 54, Nommers $3 \& 4$, September en Desember 2013

For Smit confessing is never final; it is an openended and ongoing dialogue. For this reason many of his essays' titles contain a question mark. He is questioning what has perhaps been seen as unquestionable. He is inviting dialogue, calling us to partake in the ongoing dialogue ...

\section{CONCLUSION}

The dialogue between historicality, orientation and contextuality is not only present in the kairos or moment of truth in the situation of a declared status confessionis; it is always present. Of course there is the moment of truth where the church cannot but confess her faith for the sake of the gospel in a public confession. But there are always little kairoi, little moments of truth, where we have to confess our faith publicly. In these little kairoi confessing does not occur in the form of a creed, but in different ways of disclosing and opposing false ideologies, inhumane customs, selfdestructive lifestyles, oppressive political structures, laws or customs.

From a hermeneutical perspective the core of Smit's theological thinking can indeed be seen as orientation and ambiguity amidst the dialectic of historicality and contextuality. The confession in the creed that Jesus is Lord is Smit's orientated direction. But this direction is not a straight and paved way, it is rather similar to the orientated direction of a river meandering through rolling hills. The contextual meaning of the creed is vague and ambiguous, it is not known offhand or beforehand. It much rather is discovered within the dialectic of historicality and contextuality, within the dialogue with the mothers and fathers, the sisters and brothers. It is an ongoing and openended way of doing theology, an adventurous discovery - even more exhilarating and dangerous than river rafting!

\section{BIBLIOGRAPHY}

Bernstein, R. J. 1982. From Hermeneutics to Praxis. Review of Metaphysics 35, 823-845.

Dutt, C. 1995. Hans-Georg Gadamer im Gespräch. Heidelberg: Universitätsverlag C. Winter.

Ebeling, G. 1969. Evangelische Evangelienauslegung. Eine Untersuchung zu Luthers

Hermeneutik. Darmstadt: Wissenschaftliche Buchgesellschaft.

Foster, M. 1991. Gadamer and Practical Philosophy. The Hermeneutics of Moral Confidence. Cunningham, L. S. (ed.). American Academy of Religion. Studies in Religion 64. Atlanta, GA: Scholars.

Fouché, H. L. 1978. Die Verstaan van Waarheid. (The Understanding of Truth.) Unpublished MA Thesis, Stellenbosch University.

Fouché, H. L. 2001. Hermeneutiek en Waarheid. 'n Kritiese Ondersoek na die Sin van die Wirkungsgeschichte in die Filosofiese Hermeneutiek van Hans-Georg Gadamer. (Hermeneutics and Truth. A Critical Investigation of the Meaning of the Wirkungsgeschichte in the Philosophical Hermeneutics of Gadamer.) Unpublished doctoral dissertation, Stellenbosch University.

Fouché, H. L. and Smit, D. J. 1996. Inviting a Dialogue on “Dialogue". Scriptura (57), 79-102. Gadamer, HG. 1974. Hermeneutics and Social Science. Cultural Hermeneutics 2, 307-316.

Gadamer, HG. 1975. Wahrheit und Methode. Grundzüge einer philosophischen Hermeneutik. 4th edition. Tübingen: J. C. B. Mohr (Paul Siebeck).

Gadamer, HG. 1976a. Hermeneutik als praktische Philosophie. Vernunft im Zeitalter der Wissenschaft. Frankfurt am Main: Suhrkamp, 78-109.

Gadamer, HG. 1976b. Was ist Praxis? Die Bedingungen gesellschaftlicher Vernunft. Vernunft im Zeitalter der Wissenschaft. Frankfurt am Main: Suhrkamp, 54-77.

Gadamer, HG. 1980. Practical Philosophy as a Model of the Human Sciences. Research in Phenomenology, IX, 7485.

Gadamer, HG. 1983. Vom Ideal der praktischen Philosophie. Lob der Theorie. Frankfurt am Main: Suhrkamp, 67-76.

Gadamer, HG. 1999. The Ethics of Value and Practical Philosophy. In Gadamer, HG. Hermeneutics, Religion, 
NGTT: Oopbron - http://ngtt.journals.ac.za

and Ethics, tr. Weinsheimer, J. New Haven, CT and London: Yale University Press, 103-118.

Kimmerle, H. 1957. Die Hermeneutik Schleiermachers in Zusammenhang seines spekulativen Denkens. Heidelberg: Universitätsbibliothek.

Riedel, M. (ed.). 1972. Rehabilitierung der praktischen Philosophie. Bd I, Geschichte - Probleme - Aufgaben. Freiburg: Rombach.

Riedel, M. (ed.). 1974. Rehabilitierung der praktischen Philosophie. Bd II, Rezeption, Argumentation, Diskussion. Freiburg: Rombach.

Schleiermacher, F. D. E. 1974. Hermeneutik-nach den Handschriften neu herausgegeben und eingeleitet von H. Kimmerle. (Zweite, verbesserte und erweiterte Ausgabe). Heidelberg: Carl Winter.

Smit, D. J. 1987. Hoe Verstaan Ons wat Ons Lees?'n Dink- en Werkboek oor die Hermeneutiek vir Predikers en Studente. (How Do We Understand what We Read? A Reasoning and Workbook on Hermeneutics for Preachers and Students.) Woord teen die Lig B/1. Cape Town: NG Kerk.

Smit, D. J. 1998a. Biblical Hermeneutics: The First 19 Centuries. In Maimela, S. and König, A. (eds.), The Rich Variety of Theology and Hermeneutics. Pretoria: Van Schaik, 275-296.

Smit, D. J. 1998b. Biblical Hermeneutics: The 20th Century. In Maimela, S. and König, A. (eds.), The Rich Variety of Theology and Hermeneutics. Pretoria: Van Schaik, 297-317.

Smit, D. J. 2007a. Essays in Public Theology. Collected Essays 1, Conradie, E. M. (ed.). Stellenbosch: Sun Press.

Smit, D. J. 2007b. "No Other Motives would Give Us the Right" - Reflections on Contextuality from a Reformed Experience. In Smit, D. J., Essays in Public Theology. Collected Essays 1, 157-178.

Smit, D. J. 2008. Geloof en Openbare Lewe. Versamelde Opstelle 2. (Faith and Public Life. Collected Essays 2.), Koopman, N. N. (ed.). Stellenbosch: Sun Press.

Smit, D. J. 2009a. Essays on Being Reformed. Collected Essays 3, Vosloo, R. R. (ed.). Stellenbosch: Sun Press.

Smit, D. J. 2009b. Confessing as Gathering the Fragments? On the Reformed Way of Dealing with Plurality and Ambiguity. In Smit, D. J. Essays on Being Reformed. Collected Essays 3, 295-306.

\section{KEY TERMS}

Historicality

Contextuality

Orientation

Dialogue

One message \& one church

\section{TREFWOORDE}

Historiese bepaaldheid

Kontekstualiteit

Oriëntasie

Dialoog

Een boodskap en een kerk

Dr. Leon Fouché

De Wetstraat 6

Stellenbosch

7600

hlfouche@mweb.co.za 